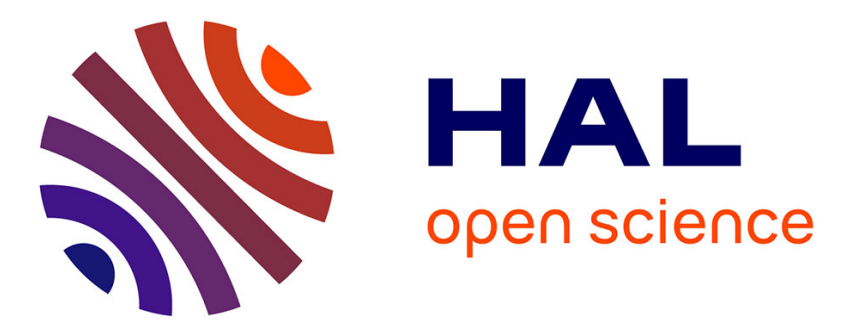

\title{
Phytochemical Screening and Polyphenolic Contents of Dialium dinklagei and Diospyros monbuttensis, Two Ivorian Medicinal Plants Used to Treat Malaria
}

Karim Tuo, Sylvain Béourou, André Offianan Touré, Karamoko Ouattara, Dieudonné Silué, Dominique Tano Konan, Marius Adagba, David Koffi, Stephane Yao, Joseph Djaman, et al.

\section{To cite this version:}

Karim Tuo, Sylvain Béourou, André Offianan Touré, Karamoko Ouattara, Dieudonné Silué, et al.. Phytochemical Screening and Polyphenolic Contents of Dialium dinklagei and Diospyros monbuttensis, Two Ivorian Medicinal Plants Used to Treat Malaria. Journal of Advances in Medical and Pharmaceutical Sciences, 2015, 2 (4), pp.144-153. 10.9734/JAMPS/2015/13779 . hal-02509207

\section{HAL Id: hal-02509207 \\ https://hal.science/hal-02509207}

Submitted on 17 Mar 2020

HAL is a multi-disciplinary open access archive for the deposit and dissemination of scientific research documents, whether they are published or not. The documents may come from teaching and research institutions in France or abroad, or from public or private research centers.
L'archive ouverte pluridisciplinaire HAL, est destinée au dépôt et à la diffusion de documents scientifiques de niveau recherche, publiés ou non, émanant des établissements d'enseignement et de recherche français ou étrangers, des laboratoires publics ou privés. 


\title{
Phytochemical Screening and Polyphenolic Contents of Dialium dinklagei and Diospyros monbuttensis, Two Ivorian Medicinal Plants Used to Treat Malaria
}

\author{
Tuo Karim ${ }^{1,2}$, Béourou Sylvain ${ }^{2}$, Touré André Offianan ${ }^{2}$, Ouattara Karamoko ${ }^{1}$, \\ Silué Kigbafori Dieudonné ${ }^{3}$, Tano Konan Dominique ${ }^{2}$, Adagba Marius ${ }^{4}$, \\ Koffi David $^{1,2}$, Yao Serge Stephane ${ }^{1,2}$, Djaman Allico Joseph \\ and Coulibaly Adama ${ }^{1}$
}

${ }^{1}$ Pharmacodynamics Biochemical Laboratory, U.F.R. Biosciences, Felix Houphouet Boigny University, Abidjan, 22 BP 582 Abidjan 22, Côte d'Ivoire.

${ }^{2}$ Department of Parasitology-Mycology, Malariology Unit, Institut Pasteur in Côte d'Ivoire, 01 Bp 490 Abidjan 01, Côte d'Ivoire. ${ }^{3}$ Department of Environment and Health, Swiss Center for Scientific Research in Côte d'Ivoire, 01 BP 1303 Abidjan 01, Côte d'lvoire. ${ }^{4}$ Department Virus Epidemic, Institut Pasteur in Côte d'Ivoire, 01 Bp 490 Abidjan 01, Côte d'Ivoire. ${ }^{5}$ Department of Medical Biochemistry and fundamental, Toxicology Unit, Institut Pasteur in Côte d'Ivoire, 01 Bp 490 Abidjan 01, Côte d'Ivoire.

\section{Authors' contributions}

This work was carried out in collaboration among all authors. Author TK designed the study and wrote the protocol. Authors BS and TAO supervised the laboratory protocols and corrected the manuscript.

Authors OK, SKD and TKD corrected the manuscript. Authors YSS, AM and KD performed the statistical analysis and also wrote part of the manuscript. Authors DAJ and CA supervised the study. All authors read and approved the final manuscript.

Article Information

DOI: 10.9734/JAMPS/2015/13779 Editor(s):

(1) Faiyaz Shakeel, Department of Pharmaceutics, King Saud University, Saudi Arabia. (2) Dongdong Wang, Department of Pharmacogonosy, West China College of Pharmacy, Sichuan University, China. Reviewers:

(1) Alli Lukman Adewale, Medical Biochemistry, College of Health Sciences, University of Abuja, Nigeria. (2) Norma Almaraz Abarca, Instituto Politécnico Nacional, México. Complete Peer review History: http://www. sciencedomain.org/review-history.php?iid=888\&id=36\&aid=7803

Original Research Article
Received $3^{\text {rd }}$ September 2014 Accepted $17^{\text {th }}$ November 2014 Published $16^{\text {th }}$ January 2015 


\section{ABSTRACT}

Introduction: Malaria is a deadly parasitic infection in its severe form. It is caused by an endoparasite protozoan transmitted by a mosquito vector. Despite considerable efforts to eradicate it, this endemic disease remains a public health problem because of its high frequency, severity and the consequences it generates. Furthermore, the existing treatments are increasingly ineffective; it is therefore urgent to find new anti-malarial drugs.

Objective: From the phytochemical screening and the determination of the polyphenolic content of Dialium dinklagei and Diospyros monbuttensis used in traditional medicine in Côte d'Ivoire to treat malaria, we identified families of chemical compounds that can guide us towards pharmacological studies. These studies allow us to identify new molecules which could be a possible alternative antimalarial reference used today because of their effectiveness in treating malaria.

Materials and Methods: From Dialium dinklagei and Diospyros monbuttensis, we obtained extracts decoction and hexane extracts, methanolic and aqueous extraction after three solvents of increasing polarity (n-hexane, methanol, water), respectively. The crude extracts obtained were tested for chemical identification of groups that may be the basis of the expected therapeutic effects. Moreover, the decoction and methanol extracts were used to determine the polyphenolic compounds.

Results: The results vary from one plant species to another and from one sample to another. Abundant presence of alkaloids in all samples and an absence of steroids in other extract except decoction extract of Diospyoros monbuttensis were observed. Therefore, the other chemical groups are present in all plants in varying proportions but depending on the mode of extraction. A higher content of phenols and tannins in Dialium dinklagei over Diospyros monbuttensis was observed. However, the content of flavonoids of Dialium dinklagei is relatively lower compared to that observed in Diospyros monbuttensis.

Conclusion: The overall results of the phytochemical screening and polyphenolic content would partly explain the traditional healers' infatuation to these plants as antimalarials.

Keywords: Malaria; natural substances; chemical groups; Dialium dinklagei; Diospyros monbuttensis.

\section{INTRODUCTION}

The high population growth, the growing impoverishment and the lack of medical facilities are the major problems faced by the most of African populations [1]. Owing to this situation, they do not always have access to imported pharmaceuticals. According to Sandhya et al. [2] and Séguéna et al. [3], $80 \%$ of the world population relies on traditional medicine for their primary health care that requires the use of plant extract. Indeed, the use of traditional medicine is justified by the treatment of many infections against which the plants are used as effective as drugs imported by Africa [3-5]. Secondary metabolites present in these plants are not new to the medical properties that are attributed to them. The search for these secondary metabolites could be the first step towards the determination of active ingredients [6,7]. That is the reason why we have undertaken the phytochemical study of plants used in the Ivorian traditional medicine against malaria. In this context, Diospyros monbuttensis Gürk (Ebenaceae) and Dialium dinklagei (Caesalpiniaceae) widely used by traditional healers but little studied for their antimalarial activity have been selected.

Diospyros monbuttensis leaves have been reported to possess antibacterial and antimalarial properties [8-10]. The antimicrobial activities of the plant leaves extract was due to the presence of tannins $[11,12]$. Other constituents that have been reported include saponins, anthraquinones, cardiac glycosides and alkaloids [8]. Dialium dinklage $i$ is a tree of Caesalpiniaceae family with trunk cylindrical right. The sheets made up have an acid taste, the flowers are of color yellow and the bark is very thick [13]. Not previously reported from Ivoiry Coast. This species is distributed in West and Central Africa and has been reported from Angola, Cameroon, D.R. Congo, Gabon, Ghana, Guinea, Ivory Coast, Liberia, Nigeria and Sierra Leone [14].

The aim of this work was to investigate the correlation between the active ingredients present in these medicinal plants and their therapeutic effects, namely their use as antimalarial medicines. 


\section{MATERIALS AND METHODS}

\subsection{Plant Material}

The plant material consisted of leaves of Diospyros monbuttensis and Dialium dinklagei. These are two plant species, which have been little studied for their antiplasmodial activity, especially Dialium dinklagei. The leaves of Diospyros monbuttensis were collected in the month of January 2013 from Talahini-Sokoura in the Department of Sandegué (North-eastern Côte d'Ivoire). Those of Dialium dinklagei were collected in March 2013 in the District of Abidjan. Plants were adult and the harvest time was chosen the morning. Plants species were identified by Professor Ake-Assi from the "Centre National de Floristique", University of FelixHouphouet-Boigny, Abidjan, Côte d'Ivoire. They were then dried in sunlight for one week at room temperature before being reduced to a fine powder by using mechanical grinder type IKAMAG. From the powder obtained after spraying the leaves, various crude extracts were prepared.

\subsection{Preparation of Crude Extracts}

First, from the fine powder obtained, decoctions of each plant were made to be as close as possible to the form of traditional use. Then we made three successive extractions with solvents of increasing polarity, according to the protocol of Békro et al. [15], Zirihi et al. [16] and Beourou et al. [17]. In the following order, we used three solvents of increasing polarity: hexane, methanol and water.

\subsection{Decoction}

The decoction was obtained by dissolving $20 \mathrm{~g}$ of fine dry powder in $1 \mathrm{~L}$ of distilled water. The whole was homogenized and boiled for 30 minutes. The preparation was first wrung out in a square of white cloth, and then filtered successively twice on an absorbent cotton and once on a Whatman filter paper $3 \mathrm{~mm}$. Filtrate 1 was thus obtained. The same operation was repeated with the residue by adding 1 liter of distilled water to obtain the filtrate 2. These two filtrates were gathered and evaporated in "Venticel" oven at $55^{\circ} \mathrm{C}$. This series of operations led to the extract of decoction.

\subsection{Extraction with Hexane}

A sample $(50 \mathrm{~g})$ of fine dry powder were dissolved in $150 \mathrm{~mL}$ of hexane. The whole was vigorously agitated in a blender for 10 minutes. The preparation was first wrung out in a square of white cloth, and then filtered successively with an absorbent cotton and filter paper. The first hexane filtrate was thus obtained (hexane filtrate 1). For filtrate 2, the same operation was repeated by addition of $150 \mathrm{~mL}$ of hexane on the residue found. This activity was repeated for filtrate 3 . These three filtrates were then gathered and evaporated in the "Venticel" oven at $55^{\circ} \mathrm{C}$. This operation led to a hexane extract.

\subsection{Extraction with Methanol}

After extraction with hexane, the residual powder was dried and then extracted with $150 \mathrm{~mL}$ of methanol. After 10 minutes of homogenization by stirring in a blender the extract was filtered through a piece of gauze for obtaining the methanolic filtrate 1 . The same operation was repeated twice more to obtain the methanolic filtrates 2 and 3 . All three filtrates were then pooled and evaporated in an oven "Venticel" at $55^{\circ} \mathrm{C}$. This series of operations led to an extract called methanol extract.

\subsection{Preparation of the Aqueous Extract}

The same operations were repeated on the residual dry powder coming from the ethanolic extraction but using $150 \mathrm{~mL}$ of distilled water. We obtained the aqueous extract.

For the following tests, the aqueous and decoction extracts are dissolved in distilled water while the other extracts are dissolved in DMSO.

\subsection{Phytochemical Screening}

Phytochemical analysis was performed on the basis of tests for coloring characteristics to highlight the major chemical groups. It focused on decoction extracts, hexane, methanol and aqueous extracts of the studied plants. Various chemical groups were identified by reference to the methods described by Nemlin and Brunel [18], Békro et al. [15] and Bruneton [19].

The results have been classified according to: Highly positive: +++; Fairly positive: ++; weakly positive: +; Negative test: - 


\subsubsection{Saponins (Foam index)}

Samples $(0.1 \mathrm{~g}$ of dry extract) were dissolved in $10 \mathrm{~mL}$ of distilled water. The samples were shaken vigorously up and down for 30-45 seconds and then left for 15 minutes. The height of the foam was measured. Persistent foam for more than $1 \mathrm{~cm}$ high indicated the presence of saponins.

\subsubsection{Steroids: Salkowski test}

Five drops of concentrated $\mathrm{H}_{2} \mathrm{SO}_{4}$ were added to $1 \mathrm{~mL}$ of extract, the apparition of a red color indicated the presence of steroids.

\subsubsection{Sterols and polyterpenes}

Extracts $(0.1 \mathrm{~g})$ were dissolved in $1 \mathrm{~mL}$ of hot acetic anhydride in a capsule. The resulted solutions were poured and added with $0.5 \mathrm{~mL}$ $\mathrm{H}_{2} \mathrm{SO}_{4}$. A violet coloration that turned in blue, and then in green revealed the presence of sterols and triterpenes.

\subsubsection{Alkaloids}

Two drops of Bouchard's reagent (reagent of iodine-iodide) were added to $1 \mathrm{~mL}$ of each extract. A red-brown precipitate indicated a positive reaction.

\subsubsection{Polyphenols}

A drop of alcoholic solution of $2 \%$ ferric chloride was added to $2 \mathrm{~mL}$ of extracts. A blue-blackish to green darkish coloration indicated a positive reaction.

\subsubsection{Anthocyanins}

Five milliliters of $10 \% \mathrm{H}_{2} \mathrm{SO}_{4}$ was added to $5 \mathrm{~mL}$ of $5 \%$ extract, and then a base (five drops of $25 \% \mathrm{NH}_{4} \mathrm{OH}$ ) was added. If the coloration is accentuated by acidification and then change into blue-purplish in a basic environment, anthocyanins were present.

\subsubsection{Leucoanthocyanins}

One milliliter of extract was added to $5 \mathrm{~mL}$ of hydrochloric alcohol. The preparation was heated in the water-bath for 15 minutes. A cherry red or purplish coloration meant the presence of leucoanthocyanins.

\subsubsection{Flavonoid}

In a tube containing $3 \mathrm{~mL}$ of extract, a few drops of $10 \% \mathrm{NaOH}$ were added. Appearance of yellow-orange color indicated the presence of flavonoids.

\subsubsection{Quinones}

An aliquot $(0.1 \mathrm{~g})$ of extract was dissolved in 5 $\mathrm{mL}$ of diluted $\mathrm{HCl}(1 / 5)$ and heated in a boiling water bath for 30 minutes, and then extracted with $20 \mathrm{~mL}$ of $\mathrm{CHCl}_{3}$ after cooling. To the organic phase was added $0.5 \mathrm{~mL}$ of $50 \% \mathrm{NH}_{4} \mathrm{OH}$ diluted solution. The positivity of the reaction was indicated by a red to violet color.

\subsubsection{Cardiotonic glycosides}

This reaction is exothermic. It takes place in a glacial environment. To $2 \mathrm{~mL}$ of aqueous solution of extract were added $1 \mathrm{~mL}$ of glacial acetic acid and then $1 \mathrm{~mL}$ of concentrated sulfuric acid. Adding few drops of $2 \% \mathrm{FeCl}_{3}$ gave a greenbluish coloration, which is specific to cardiotonics glycosides.

\subsubsection{Coumarins}

To $5 \mathrm{~mL}$ of extract, $2 \mathrm{~mL}$ of hot water were added, and then the solution was shared between two test tubes. In the content, we added $0.5 \mathrm{~mL}$ of $25 \% \mathrm{NH}_{4} \mathrm{OH}$. Under the UV light (366 $\mathrm{nm}$ ), an intense fluorescence indicated the presence of coumarins.

\section{$\underline{\text { 2.7.12 Tannins }}$}

Two milliliters of water and few drops of $1 \%$ ferric chloride were added to $1 \mathrm{~mL}$ of extract. The appearance of a blue, blue-black or black coloration indicated the presence of gallic tannins, the green or dark green coloration showed the presence of catechic tannins.

\subsection{Determination of Polyphenols}

The polyphenol contents were determinated for the foliar decoction and methanol extracts of Diospyros monbuttensis and Dialium dinklagei.

\subsection{Determination of Total Phenols}

The total phenolic content of plant extracts was determined by the Folin-Ciocalteu method $[20,21]$. To $0.5 \mathrm{~mL}$ of each plant extract of concentration $100 \mathrm{mg} / \mathrm{mL}$ were added $5 \mathrm{~mL}$ of 
Folin-Ciacolteu reagent diluted $1 / 10$ in distilled water and $4 \mathrm{~mL}$ of sodium carbonate $(1 \mathrm{M})$. The mixture was incubated at room temperature for 15 minutes. Then, the absorbance was registered at $765 \mathrm{~nm}$ in a spectrophotometer against a blank. Gallic acid was used to construct a standard curve in order to calculate the phenol contents, which was prepared under the same conditions as above with a solvent mixture of methanol/water (50: 50, V/N) at concentrations ranging from 0 to $200 \mathrm{mg} / \mathrm{mL}$. Experimentations were carried out in triplicate. The total phenolic contents of the extracts were expressed as gallic acid equivalents/g dry extract (mg GAE/g dry extract).

\subsection{Determination of Total Flavonoids}

The technique used to determine the contents of total flavonoids in the extracts was the colorimetric method of aluminum chloride $[22,23]$. And $0.5 \mathrm{~mL}(100 \mu \mathrm{g} / \mathrm{mL})$ of each plant extract were taken, to which $1.5 \mathrm{~mL}$ of methanol, $0.1 \mathrm{~mL}$ of $10 \%$ aluminum chloride, $0.1 \mathrm{~mL}$ of potassium acetate $(1 \mathrm{M})$ and $2.5 \mathrm{~mL}$ of distilled water were successively added. After incubation at room temperature for 30 minutes, the optical densities were measured in a spectrophotometer at 415 $\mathrm{nm}$. A methanolic solution of quercetin in concentrations ranging from 0 to $100 \mu \mathrm{g} / \mathrm{mL}$ were used to construct a standard curve in order to calculate the flavonoid contents. Experimentations were carried out in triplicate. The contents of flavonoids were expressed as quercetin equivalents/g dry extract (mg QE/g dry extract).

\subsection{Determination of Tannins}

The tannin contents were calculated by using the modified vanillin method of Bainbridge et al. [24]. This method is based on the fact that the tannic acid (especially the flavan-3-ol) in the presence of the vanillin reagent $(0.1 \mathrm{mg} / \mathrm{mL})$ in an acid medium (sulfuric acid $70 \%(\mathrm{v} / \mathrm{v})$ gives a red color whose maximum absorption is $500 \mathrm{~nm}$. The standard solution consists of tannic acid (0.1 $\mathrm{mg} / \mathrm{mL}$ ) prepared in $98 \%$ methanol. A range of standard was prepared with a series of 6 tubes where the first represents a blank. In the other 5 tubes are introduced respectively $0.2 ; 0,4 ; 0.6$; $0.8 ; 1 \mathrm{ml}$ of standard solution and complete the volume of each tube with $1 \mathrm{ml}$ of distilled water. The test tube contains $1 \mathrm{ml}$ of extract. To each of them are added $5 \mathrm{ml}$ of vanillin reagent. After 30 minutes of incubation in the dark, the absorbance was read at $500 \mathrm{~nm}$ against a blank (without extract). The tannic acid $(1 \mathrm{mg} / \mathrm{ml})$ was used to construct a standard curve in order to calculate the tannin contents. Experimentations were carried out in triplicate. The results were expressed as $\mathrm{mg}$ of tannic acid equivalents/g dry extract (mgTAE/g dry extract)

\subsection{Statistical Analysis}

Graphical representations of data were performed using the Graph Pad Prism 5.0 software (Microsoft, USA). The test results were expressed as mean \pm SD. Multiple comparisons and determination of significance level are made by the univariate ANOVA followed by Tukey test. The differences were considered statistically significant at the 0.05 level.

\section{RESULTS AND DISCUSSION}

\subsection{Plant Selection and the Output of the Extraction}

The investigations were carried out with ethnobotanical approaches among stakeholders of traditional medicine, especially herbal traders operating on the markets of the District of Abidjan. These investigations resulted in the selection of Diospyros monbuttensis and Dialium dinklagei, widely used by Ivorian traditional pharmacopoeia and very little studied for their antimalarial activity. These species were mainly collected on the basis of indications by literature and information received from healers.

Decoctions produced the highest output $(20 \%)$, and hexane was the smallest (1\%). These results suggest the use of the method of extraction decoction as indicated for the preparation of extracts from these plants base (Figure 1). The very low output obtained with hexane shows that the studied plants contain very little non-polar compounds. This result is similar to the one obtained by Bekro et al. [15] $(0,75 \%)$ with Caesalpinia benthamiana (Baill.).

\subsection{Phytochemical Screening}

The results of the phytochemical screening carried out on the extracts of plants referred to malaria are mentioned in the Table 1. Chemical composition variations were found among the different extracts and between the two plant species analyzed. 


\subsection{Diospyros monbuttensis}

The leaves contain sterols, polyterpenes, polyphenols, flavonoids, alkaloids, saponins, leucoanthocyanins, tannins, quinones and coumarins. Anthocyanins, cardiac glycosides and steroids are present at very small quantities. These results are different from those of Anie et al. [9], who reported the absence of tannins in roots and stem bark. They were similar to those of Bouquet and Debray [25] which showed the presence of quinones, tannins, sterols and saponins in the leaves and differ from ours by the absence of flavonoids and alkaloids. Previous studies [8] reported the presence of saponins, anthraquinones, cardiac glycosides and alkaloids. According Bouquet and Debray [25], this plant is considered to be a good remedy for stiffness, stomach ache, edema and leprosy by Baoule and Agni ethnies of Côte d'Ivoire. The antimalarial therapeutic indication may be related to the presence of alkaloids because we know that the majority of antimalarial drugs belong to the same chemical family [26]. Various studies have shown that coumarins have a high antioxidant capacity. This antioxidant activity is due to their capacity to scavenging free radicals and chelating metal ions [27]. Analgesics and anti-inflammatories activities are attributed to tannins. Tannins also contribute to wounds healing [28].

\subsection{Dialium dinklagei}

The decoction of the leaves contains sterols, polyterpenes, polyphenols, flavonoids, alkaloids, coumarins and saponins in large quantities. Anthocyanins, leucoanthocyanins, tannins, quinones and cardiac glycosides are present in small quantities. There was also an absence of steroids. These results were comparable to those of Akoué [13], who noted a large presence of flavonoids, alkaloids, tannins and polyphenols in the ethanol extract of the leaves. Very little research has been made on this plant, but our results confirm those of Bouquet and Debray [25] about the presence of tannin in the leaves of $D$. dinklagei. Sterols, saponins, alkaloids and polyterpenes help explain its traditional therapeutic uses. In addition to their industrial applications as surfactants, traditionally saponins are widely used as detergents, pesticides and mollucides and foam, and can also have advantages on health [29].

\subsection{Polyphenol Content of Diospyros monbuttensis and Dialium dinklagei}

The contents of total phenols in the plant extracts, determined from a calibration curve of gallic acid $\left(Y=0.01810 X+0.07179 ; R^{2}=0.9911\right)$ showed that Dialium dinklagei is richer in phenols than Diospyros monbuttensis, whatever the type of solvent used. The highest content was obtained in the methanolic extract of Dialium dinklagei. These levels ranged from 114.1 $\mathrm{mgGAE} / \mathrm{g}$ and $205.1 \mathrm{mgGAE} / \mathrm{g}$ (Table 2). The difference between the contents of the phenol based on the plant and solvent used is highly significant $(p<0.0001)$.

$\infty$ Diospyros monbuttensis

Dialium dinklagei

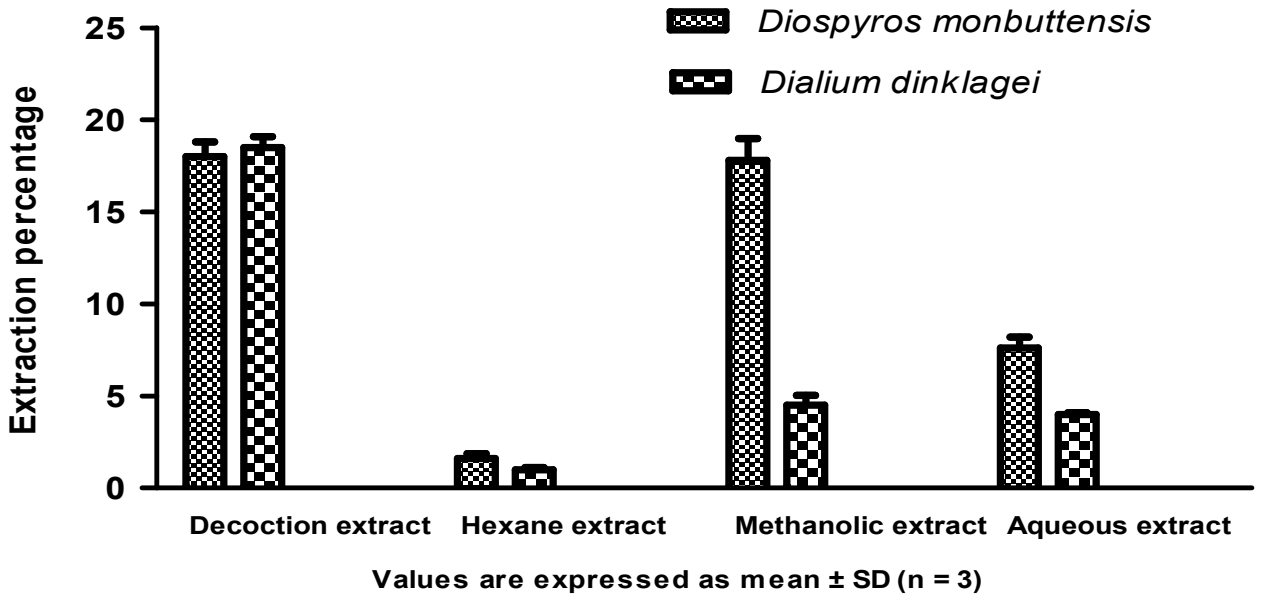

Figure 1. Yields of extracts (\%) 
Table 1. Results of the foliar phytochemical tests

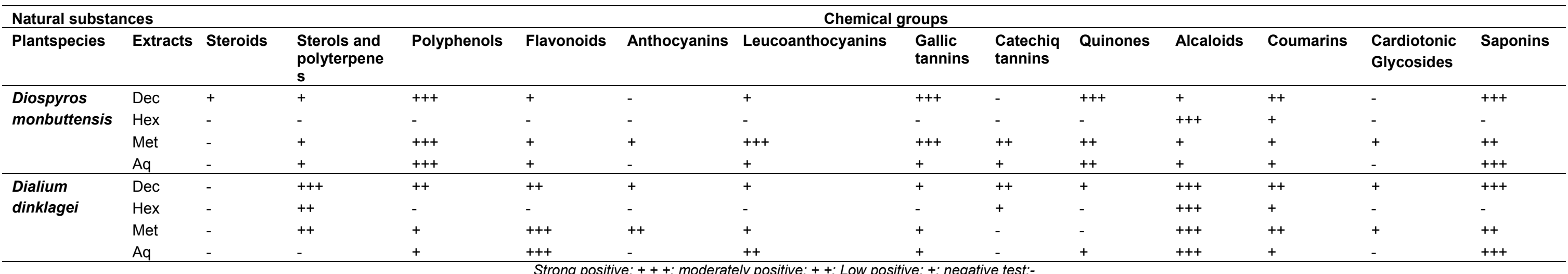

Strong positive: ++++ moderately positive: $++;$ Low positive: + ; negative test:-
Dec: Decoction extract; Hex: Hexane extract; Met: Methanolic extract; Aq: Aqueous extract

Table 2. Total phenols, flavonoids and tannins contents of extracts

\begin{tabular}{|c|c|c|c|c|c|c|}
\hline & \multicolumn{2}{|c|}{$\begin{array}{c}\text { Phenol content } \\
\text { (mgGAE/g dry extract) }\end{array}$} & \multicolumn{2}{|c|}{$\begin{array}{l}\text { Flavonoid content } \\
\text { (mgQE/g dry extract) }\end{array}$} & \multicolumn{2}{|c|}{$\begin{array}{c}\text { Tannin content } \\
\text { (mgTAE/g dry extract) }\end{array}$} \\
\hline & Decoction extract & Methanolic extract & Decoction extract & Methanolic extract & Decoction extract & Methanolic extract \\
\hline Diospyros monbuttensis & $136,54 \pm 12,63$ & $114,10 \pm 2,43$ & $62,18 \pm 2,03$ & $15,25 \pm 1,13$ & $46,50 \pm 1,00$ & $85,70 \pm 3,25$ \\
\hline Dialium dinklagei & $185,59 \pm 5,89$ & $205,07 \pm 9,09$ & $6,780 \pm 0,61$ & $10,90 \pm 1,52$ & $146,4 \pm 5,46$ & $108,7 \pm 6,85$ \\
\hline
\end{tabular}


The results of the flavonoid contents of the different extracts of both plants species analyzed, determined from a calibration curve of quercetin $\left(Y=0.02834 X+0.01368 ; R^{2}=0.9986\right)$ showed that Diospyros monbuttensis is richer in flavonoids than Dialium dinklagei. The differences between the amounts of flavonoids according to the plant species and the solvent used were significant $(p<0.0001)$. These amounts vary between $6.78 \mathrm{mgQE} / \mathrm{g}$ and 62.18 $\mathrm{mgQE} / \mathrm{g}$ (Table 2). The highest amount was obtained in the decoction extract of Diospyros monbuttensis (62.18 mgQE/g).

Tannins from different plant extracts were determined from a calibration curve of tannic acid $\left(Y=0.2167 X-0.004417 ; R^{2}=0.9761\right)$. Whatever the type of solvent used, the results showed that Dialium dinklagei is richer in tannins than Diospyros monbuttensis; the highest amount was obtained in the decoction extract of Dialium dinklagei. These contents ranged from 46,50 $\mathrm{mgTAE} / \mathrm{g}$ and $146.4 \mathrm{mgTAE} / \mathrm{g}$ (Table 2). Statistically, the difference between the contents of the phenols concerning the plant species analyzed and the type of solvent used were highly significant $(p<0.0001)$.

The analysis of variance (ANOVA) and the postANOVA test (Tukey's multiple comparison test) have shown that the means of different contents of phenol, tannins and flavonoids of the two plant species were significantly different. When compared to those obtained by Akoue et al. [13] (4.42 $\pm 0.45 \mathrm{mgGAE} / \mathrm{g}$ for the aqueous extract and $2.27 \pm 0.0038 \mathrm{mgGAE} / \mathrm{g}$ ethanolic extract), the contents of phenol Dialuim dinklagei for methanolic and aqueous extracts were very high. This difference could be due to the extraction solvent and the method used.

In general, the decoction gave the highest contents of phenols, flavonoids and tannins. One the hand, the increase in temperature favors the diffusion and solubility of substances extracted. On the other hand, it destroys certain fragile substances [30]. This increase of the contents of flavonoids in the decocted extract of Diospyros monbuttensis can be explained by the destruction by the heat of polyphenol oxidases (PPO) that lowers the polyphenol content; thus the breaking of the connection between polyphenols and other substances leading to the accessibility of these active principles may explain this abundance [31]. The flavonoid content of Dialium dinklagei, relatively low in relation with that of Diospyros monbuttensis, which is high in total phenol, could be explained by the presence of other phenolic compounds such as coumarins. The tannin content in Dialium dinklagei was higher than that of Diospyros monbuttensis. This difference may be related to the species of the studied plants, which were different. Tannins are usually defined as natural polyphenolic compounds with high molecular weight, capable of forming complexes with proteins, their effects on animals are various [32]. Thus, these compounds provide protection against cardiovascular diseases, immune/ autoimmune diseases, brain disorders such as Parkinson's disease, and Alzheimer's disease [33]. Traditional medicinal use of these plants is well justified because it is now recognized that phenolic compounds have a significant therapeutic interest: fight against atherosclerosis, anticarcinogenic actions, a major source of natural antioxidants to fight against cellular aging $[34,35]$. Furthermore the phytochemical sorting revealed that in addition to phenols, flavonoids and tannins, these plants also contain polyterpenes, saponins and alkaloids which contribute to their various therapeutic activities.

\section{CONCLUSION}

The overall results of the phytochemical screening and polyhenolic content partly and rationally explain the interest of traditional healers for these plants as antimalarial plants. The therapeutic effects can be induced by various chemicals (alkaloid, flavonoids, polyphenols, polyterpenes, saponins, sterols and catechic tannins) which form the scientific basis of traditional therapeutic use of the studied plants. The in vivo and in vitro studies and the determination of the structure of active molecules will deepen the study of the antimalarial activity of these plants.

\section{CONSENT}

Not applicable.

\section{ETHICAL APPROVAL}

The study been performed in accordance with the ethical requirements in force in Ivory Coast.

\section{ACKNOWLEDGEMENTS}

We are indebted to Professor Aké-Assi Laurent (Laboratory of Botany, Unité de Formation et de Recherche-Biosciences, University of Felix 
Houphouet-Boigny/Abidjan, Côte d'lvoire) for botanical identification of the plants.

We also thank Dr. ETTIEN Yapo for the English translation of the manuscript.

\section{COMPETING INTERESTS}

Authors have declared that no competing interests exist.

\section{REFERENCES}

1. Diaby B, Kroa E, Niare A, Coulibaly D, Traore Y, Giani S, et al. Connaissances, attitudes et pratiques des tradipraticiens de la sante de la ville d'Abidjan sur le paludisme. Mali Med. 2011;Tome XXVI $\mathrm{n}^{\circ} 3,8-12$.

2. Sandhya B, Thomas S, Isabel W, Shenbagarathai R. Ethnomedicinal plants used by the valaiyan community of Piranmalai hills (Reserved forest), Tamil Nadu, India - A pilot study. Compl and Alter Med. 2006;3:101-114.

3. Séguéna F, Soro K, Soro D, N'guessan K. Savoir-faire de populations locales des taxons du jardin Botanique de Bingerville, Côte d'Ivoire. J Appl Biosci. 2013; 68:5374-5393.

4. Kerharo J, Bouquet A. Plante medecinale et toxique de Côte d'Ivoire et Haute-Volta, mission d'étude de la pharmacopée indigène en AOF. Ed Vigot frère, Paris. 1950;300.

5. Pousset. Plantes médicinales Africaine. Utilisation pratique. Deuxième Tome, ACCT, Paris. 1989;156.

6. Anthony JP, Fyfe I, Smith H. Plant active components-a resource for antiparasitic agents? Trends in Parasitol. 2005;21:462468.

7. Toyang NJ, Verpoorte R. A review of the medicinal potentials of plants of the genus Vernonia (Asteraceae). J of Ethnopharm. 2013;146:681-723.

8. Kayode J, Omotoyinbo MA. Ethnobotanical utilization and conservation of chewing sticks plants species in Ekiti State, Nigeria. Res J. Botany. 2009;4:1-9.

9. Anie $\mathrm{CO}$, Matthew IA, Okeri HA. Antimicrobial activity of crude extracts of Diospyros monbuttensis (Fam: Ebenaceae) root and stem barks. Inter $\mathrm{J}$ of Biomedical Res. 2011;1:18-24.

10. Olasehinde G, Olusola O, Obashola F, Singh R, Adesola A. In-vitro studies on the sensitivity pattern of Plasmodium falciparum to antimalarial drugs and local herbal extracts. Mal J. 2012;11(Suppl 1):P72.

11. Odelola HA, Okorosobo VI. Preliminary investigation of in vitro Antimicrobial Activity of two Nigerian Diospyros sp. (Ebenaceae). Afri J Med Sci. 1988; 17(4):167-170.

12. Mallavadhani UV, Panda AK, Rao YR. Pharmacology and chemotaxonomy of Diospyros. Phytochem. 1998;49:901-51.

13. Akoué GN, Obame LC, Ondo JP, Brama I, Mbading-Mbading W, Otogo N'nang ES, et al. Ethnotherapy study, phytochemical and antiradical activities of Agelaea pentagyna (Lam) Baill and Dialium dinklagei Harms. Medicinal plants from Gabon. Inter J of Adv Res. 2013;1:246-255.

14. Lock JM. Legumes of Africa: a Check-List. Royal Botanic Gardens, Kew, Richmond, United Kingdom. 1989;619.

15. Békro YA, Békro JAM, Boua BB, TRA $\mathrm{BFH}$, Ehilé EE. Etude ethnobotanique et screening phytochimique de Caesalpinia benthamiana (Baill.) Herend. et Zarucchi (Caesalpiniaceae). Rev Sci Nat. 2007;4:217-225.

16. Zirihi GN, Kra AKM, Guede-Guina F. Évaluation de l'activité antifongique Microglossa Pirifolia (Larmarck) O. Kuntze (Asteraceae) «PYMI » sur la croissance in vitro de Candida albicans. Rev de Med et Ph Afr. 2003;17:11-18.

17. Nemlin J, Brunel JE. Fascicule de Travaux Pratiques de Matière Médicale (3e année). Université Nationale de Côte-d'Ivoire. Faculté de Pharmacie. Département de Pharmacognosie. Laboratoire de Phytologie, $47 \mathrm{p} ; 1995$.

18. Béourou $\mathrm{S}$, Tuo $\mathrm{K}$, Ouattara $\mathrm{K}$, Touré $\mathrm{AO}$, Meité S, Ako AAB, et al. Phytochemical screening of some medicinal plants used to treat malaria in Côte d'lvoire (West Africa). Intern $\mathrm{J}$ of Chem and Pharm Sc. 2014;2:919-925.

19. Bruneton J. Pharmacognosie, Phytochimie, Plantes médicinales. Paris, $4^{\text {ème }}$ Edition Lavoisier; 2009.

20. Mcdonald S, Prenzler PD, Autolovich M, Robards K. Phenolic content and antioxidant activity of olive oil extracts. Food Chem. 2001;73:73-84.

21. Li HB, Cheng KW, Wong CC, Fan KW, Chen $F$, Jiang $Y$. Evaluation of antioxidant capacity and total phenolic content of 
different fractions of selected microalgae. Food Chem. 2007;102:771-776.

22. Bahorun T, Gressier B, Trotin F, Brunete C, Dine T, Vasseur J, et al. Oxygen species scavenging activity of phenolic extracts from hawthorn fresh plant organs and pharmaceutical preparations. Arzneimitte-For. 1996;46:1086-1089.

23. Chang $C$, Yang $M$, Wen $H$, Chern J. Estimation of total flavonoid content in propolis by two complementary colorimetric methods. J Food Drug An. 2002;10:178-182.

24. Bainbridge $Z$, Tomlins $K$, Westby A. Analysis of condensed tannins using acidified vanillin. $\mathrm{J}$ of $\mathrm{F}$ Sc and Agr. 1996;29:77-79.

25. Bouquet A, Debray M. Plantes médicinales de Côte-d'Ivoire, Imprimerie Louis Jean, Paris (France). 1974;232.

26. Zirihi G N, N'guessan K, Etien DT, Seri KBP. Evaluation in vitro of antiplasmodial activity of ethanolic extracts of Funtumia elastica, Rauvolfia vomitoria and Zanthoxylum gilletii on Plasmodium falciparum isolates from Côte d'Ivoire. J of An \& PI Sc. 2009;5:406-413.

27. Tseng A. Chemoprevention of tumors in MTV-H ras transgenic mice with coumarins. Proc Am Assoc Cancer Res. 1991;32:2257.

28. Okwu DE, Josiah C. Evaluation of the chemical composition of two Nigerian medicinal plants. Afr $J$ Biotech. 2006;5:357-361.
29. Shi J, Arunasalam K, Yeung DY, Kakuda Mittal G, Jiang Y. Saponins from edible legumes: Chemistry, processing and health benefits. J Med Food. 2004;7:67-78.

30. Jokić $S$, Velić $D$, Bilić $M$, Bucić-Kojić $A$, Plan inić $M$, Tomas $S$. Modelling of the process of solid-liquid extraction of total polyphenols from soybeans. J Food Sci. 2010;28:206-212.

31. Lutz M, Henríquez C, Escobar M, Chemical composition and antioxidant properties of mature and baby artichokes (Cynara scolymus L.), raw and cooked. J of Food Compos Anal. 2011;24:49-54.

32. Yang CMJ, Russell JB. Resistance of proline-containing peptides to ruminal degradation in vitro. Appl Environ Microbiol. 1992;58:3954-3958.

33. Han $X$, Shen $T$, Lou $H$. Dietary Polyphenols and their biological significance. Inter J of Mol Sc. 2007; 950988.

34. Hagerman AE, Riedl KM, Jones GA, Sovik KN, Ritchard NT, Hartzfeld PW, Riechel TL. High molecular weight plant polyphenolics (tannins) as biological antioxidants. J Agric Food Chem. 1998;46:1887-1892.

35. Kumar GS, Nayaka H, Dharmesh SM; Salimath PV. Free and bound phenolic antioxidant in amla (Emblic offinalis) and turmeric (Curcuma longa). J Food Compos Anal. 2006;19:446-452.

(c) 2015 Tuo et al.; This is an Open Access article distributed under the terms of the Creative Commons Attribution License (http://creativecommons.org/licenses/by/4.0), which permits unrestricted use, distribution, and reproduction in any medium, provided the original work is properly cited.

Peer-review history:

The peer review history for this paper can be accessed here:

http://www.sciencedomain.org/review-history.php?iid=888\&id=36\&aid=7803 